\title{
Effects of the Replacement of Soybean Meal with Pea as Dietary Protein Source on the Serum Protein Fractions of Broilers
}

\section{-Author(s)}

\author{
Bingol NT \\ Dede S" \\ Karsli MA \\ Değer Y" \\ Kiliçalp Kılınç D \\ Çetin S"
}

Department of Animal Nutrition and Nutritional Diseases, Veterinary Medicine Faculty, Yuzuncu Yil University, Van, Turkey.

" Biochemistry Department Veterinary Medicine Faculty, Yuzuncu Yil University Van, Turkey.

III Department of Animal Nutrition and Nutritional Diseases, Veterinary Medicine Faculty, Kirikkale University, Kirikkale, Turkey.

iv Adnan Menderes University, Aydin Health School, Aydin, Turkey.

\section{nail Address}

Corresponding author e-mail address Dede $\mathrm{S}$

Biochemistry Department Veterinary Medicine Faculty, Yuzuncu Yil University Van, 65080, Turkey.

Tel: $\quad$ +904322251701

Email: sdede@yyu.edu.tr

\section{EKeywords}

Broiler, diet, peas, serum protein fractions.

\section{ABSTRACT}

The aim of this study was to determine the effects of the replacement of different levels of protein derived from soybean meal with that from peas in broiler diets on serum protein fractions. A corn-soybean meal basal diet was formulated as the control diet (Control=C) (NRC, 1994), and then pea was added to the control diet to replace $20 \%$ (P20) or 40\% (P40) of the crude protein of the control diet. The diets were randomly fed to 12 pens per treatment, each housing five birds, for 42 days. Blood samples were collected from 36 birds (3 birds $\times 4$ pens $\times 3$ treatments) and the serum protein fractions were separated. Gamma-globulin percentage was higher in group P20 compared with $\mathrm{C}$ and P40 groups. Total protein, beta-globulin, and gamma-globulin concentrations were significantly higher in group P20 compared with those of both control and P40 group $(p<0.05)$.

\section{INTRODUCTION}

After the ban of the use of animal products as protein sources in the livestock diets (European Commission Decisions No. 98/272/CE and 2000/374/CE), producers were forced to utilize soybeans (Glycinemax L. Merr.) in poultry diets due to its particularly high protein content. Nevertheless, consumer resistance has developed against the inclusion of soybeans in many places, because most of it derives from genetically modified crops and cannot be used in for organic farming (Vicenti et al., 2009). The cost of soybeans also dramatically increased after the ban, increasing feed costs. The increase in feed costs and the restrictions on the supply of conventional animal protein sources to livestock has stimulated researchers to evaluate the use of alternative local legume protein sources that are not commonly utilized in poultry diets (Laudadio \& Tufarelli, 2010).

Under these circumstances, researchers have started to search for non-genetically modified feedstuffs that could meet the protein requirements of poultry. One protein source alternative to soybean may be peas (Pisum sativum L.), which is widely produced in the Mediterranean region and has high nutritional values (Ravindran \& Blair, 1992; Castell et al., 1996). Although pea seeds are significantly high in starch compared with many other cereal grains, their use is still very limited in poultry diets. It is well-known that starch is the greatest single dietary source of energy in animal diets (Longstaff \& McNab, 1987).

Peas have been used for a natural source of plant protein in human and animal nutrition (Mariotti et al., 2001; Musa et al., 2012). The aqueous extract of green peas contains three fractions (albumin, legumin, and vicilin) (Malley et al., 1975). 
The two main protein groups in blood serum are albumin and globulin. Serum proteins can be further separated by electrophoresis into five protein fractions (albumin, and $\alpha 1-, \alpha 2-, \beta$-, and $\gamma$-globulins). Serum protein electrophoresis (SPEP) measures the levels of specific proteins in the blood to help identifying various conditions, such as nutritional deficiencies, some diseases, liver disorders, acute inflammatory and proliferative diseases, immune status, tissue damage like trauma, and many physiological disorders (Manojlović et al., 1993; Erstad, 1996; Karagul et al., 2000; Mehmetoglu, 2002; Murray, 2003; SPEP).

The objective of this study was to investigate the effects of the replacement of soybean meal with peas at different levels as dietary protein source on the serum protein fractions of broilers.

\section{MATERIAL AND METHODS}

\section{Birds and housing}

A total of 60 one-day-old Ross 308 broilers, obtained from a commercial hatchery, were allotted according to initial body weight into the 12 floor pens (five birds/ pen) on wood-shavings litter in an environmentallycontrolled room. The temperature was maintained at $35^{\circ} \mathrm{C}$ during the first week and then gradually reduced to $22^{\circ} \mathrm{C}$ at 35 days of age. The birds received $23 \mathrm{~h}$ of fluorescent illumination per day and were allowed free access to the diets and clean water. The experimental procedures were approved by Yuzuncu Yil University Animal Ethics Committee.

\section{Treatments}

The starter diet contained $24 \%$ crude protein (CP) and $13.2 \mathrm{MJ}$ metabolizable energy/ $/ \mathrm{kg}$ and was fed from weeks 1 to 3, and the finisher diet (21\% CP and $13.5 \mathrm{MJ} / \mathrm{kg}$ ) was fed from weeks 4 to 6 weeks. The chemical composition of the feedstuffs used in the diets was analyzed before feed formulation. A corn-soybean meal basal diet was formulated as the control diet (Control=C) (NRC, 1994), and then pea was added to the control diet to replace $20 \%$ (P20) or $40 \%$ (P40) of the crude protein of the control diet. The composition and chemical analyses of the starter and finisher diets are presented in Tables 1 and 2. The diets were randomly fed to 12 pens per treatment, each housing five birds, for 42 days.
Table 1 - Composition of the starter diets (Weeks 1-3)

\begin{tabular}{lccc}
\hline & \multicolumn{3}{c}{ Diets } \\
\cline { 2 - 3 } & $\mathrm{C}$ & $\mathrm{P} 20$ & $\mathrm{P} 40$ \\
\hline Ingredients [\%] & & \\
Corn & 48.02 & 44.87 & 41.70 \\
Soybean meal & 41.16 & 32.94 & 24.71 \\
\hline Pea & - & 11.32 & 22.64 \\
\hline Sunflower Oil & 5.68 & 5.68 & 5.68 \\
\hline Fish Meal & 2 & 2 & 2 \\
\hline Limestone & 2.05 & 1.5 & 1.5 \\
\hline Di calcium phosphate & 0.20 & 0.85 & 0.85 \\
\hline Vit+Min premix & 0.30 & 0.30 & 0.30 \\
\hline DL- Methionine & 0.15 & 0.20 & 0.29 \\
\hline NaCl & 0.44 & 0.34 & 0.33 \\
Analysis [\%] & & & \\
\hline Dry Matter & 93.20 & 93.61 & 93.83 \\
Crude protein & 23.66 & 23.88 & 23.78 \\
Ash & 7.64 & 5.02 & 6.75 \\
\hline Ether Extract & 6.69 & 7.22 & 6.86 \\
\hline Crude Fiber & 4.74 & 5.26 & 4.97 \\
*ME (MJ/kg) & 13.21 & 13.26 & 13.25 \\
\hline
\end{tabular}

Vitamin-Mineral premix (IU or mg kg-1 diet): Vitamin A: 12000 IU; Vitamin D: 1500 IU; Vitamin $\mathrm{E}: 30 \mathrm{mg}$; Vitamin $\mathrm{K}_{3}: 5 \mathrm{mg}$; Vitamin $\mathrm{B}_{1}: 3 \mathrm{mg}$; Vitamin $\mathrm{B}_{2}: 6$ mg; Vitamin $\mathrm{B}_{6}$ : 5 mg; Vitamin $B_{12}: 0.03$ mg; Nicotine amid: 40 mg; Calcium-D-pantothenate: 10 mg; Folic acid: 0.075 mg; Choline chloride: 375 mg; Antioxidant: 10 mg; Manganese: 80 mg; Iron: 80 mg; Zinc: 60 mg; Copper: 8 mg; lodine: 0.5 mg; Cobalt: 0.2 mg; Selenium: $0.15 \mathrm{mg}$.

*Metabolizable energy calculated according to Titus and Fritz (1971).

Table 2 - Composition of the finisher diets (Weeks 4-6)

\begin{tabular}{|c|c|c|c|}
\hline & \multicolumn{3}{|c|}{ Diets } \\
\hline & C & P20 & P40 \\
\hline \multicolumn{4}{|l|}{ Ingredients [\%] } \\
\hline Corn & 56.35 & 53.85 & 51.32 \\
\hline Soybean meal & 33.03 & 26.44 & 19.85 \\
\hline Pea & - & 9.06 & 18.12 \\
\hline Sunflower Oil & 5.88 & 5.88 & 5.88 \\
\hline Fish Meal & 2 & 2 & 2 \\
\hline Limestone & 2 & 2 & 2 \\
\hline Di calcium phosphate & 0.11 & - & - \\
\hline Vit+Min premix & 0.30 & 0.30 & 0.30 \\
\hline DL- Methionine & 0.06 & 0.09 & 0.16 \\
\hline $\mathrm{NaCl}$ & 0.27 & 0.38 & 0.37 \\
\hline \multicolumn{4}{|l|}{ Analysis [\%] } \\
\hline Dry Matter & 93.59 & 93.66 & 93.25 \\
\hline Crude protein & 21.18 & 21.45 & 21.38 \\
\hline Ash & 6 & 5.24 & 5.08 \\
\hline Ether Extract & 7.24 & 7.73 & 6.70 \\
\hline Crude Fiber & 5.28 & 4.79 & 4.35 \\
\hline${ }^{*} \mathrm{ME}(\mathrm{MJ} / \mathrm{kg})$ & 13.50 & 13.59 & 13.60 \\
\hline
\end{tabular}

Vitamin-Mineral premix (IU or mg kg-1 diet): Vitamin A: 12000 IU; Vitamin $D_{3}: 1500$ IU; Vitamin $\mathrm{E}: 30 \mathrm{mg}$; Vitamin $\mathrm{K}_{3}: 5 \mathrm{mg}$; Vitamin $\mathrm{B}_{1}: 3 \mathrm{mg}$; Vitamin $\mathrm{B}_{2}: 6 \mathrm{mg}$; Vitamin $\mathrm{B}_{6}$ : $5 \mathrm{mg}$; Vitamin $\mathrm{B}_{12}: 0.03 \mathrm{mg}$; Nicotine amid: $40 \mathrm{mg}$; Calcium-D-pantothenate: $10 \mathrm{mg}$; Folic acid: 0.075 mg; Choline chloride: 375 mg; Antioxidant: 10 mg; Manganese: 80 mg; Iron: 80 mg; Zinc: 60 mg; Copper: 8 mg; lodine: 0.5 mg; Cobalt: 0.2 mg; Selenium: $0.15 \mathrm{mg}$.

*Metabolizable energy calculated according to Titus and Fritz (1971). 


\section{Collection of blood samples}

On day, blood samples were collected from the wing vein from three birds per replicate, totaling 36 birds (3 birds $\times 4$ pens $\times 3$ treatments). Serum samples was separated by centrifugation at $500 \mathrm{~g}$ for $10 \mathrm{~min}$ for biochemical analyses.

\section{Biochemical analyses}

Total protein blood levels were determined by the biuret method. Serum protein fractions were separated using the Helena Lab-Titan $1{ }^{\circledR}$ Serum Protein Electrophoresis device (Cat No. 3023), Helena Lab - Titan III Cellulose acetate cards, and Electra HR Buffer (Cat No. 5805), and buffer solutions (Helena, Bioscience Europe, UK). The obtained bands were evaluated for serum protein fractions using the software Platinum 3.0.

\section{Statistical Analysis}

The data were subjected to one-way analysis of variance. Duncan test was applied for multiple comparisons of the means. Differences were considered significant at $p<0.05$ using the SPSS 22.0 statistical software.

\section{RESULTS}

The serum protein fraction bands obtained by electrophoresis were assessed using the software Platinum 3.0, and the serum levels of albumin; alpha 1, alpha 2, beta, and gamma globulins and their percentages relative to total protein levels were determined, andalbumin to globulin ratio was calculated.
Total protein concentration was significantly higher in the group P20 compared with that of both control and P40 groups $(p<0.05)$. Albumin, and alpha 1 and 2 globulin concentrations were not different among treatments. Beta-globulin concentration significantly higher in group P20 compared with that of control and group P40 $(p<0.05)$. The percentage of gamma globulin was higher in group P20 compared with that of group P40 $(p<0.05)$, but similar to that of the control group. The percentages of the other blood protein fractions and $A / G$ ratio were not affected by dietary treatment. Gama-globulin concentrations were significantly higher in group P20 compared with both the control and P40 groups $(p<0.05)$.

\section{DISCUSSION}

Some pea cultivars show considerable potential as plant protein sources for broilers (Cowieson et al., 2003). Dietary pea inclusion was shown to improve the performance and meat quality of broiler chickens (Laudadio \& Tufarelli, 2010). Evaluating four whiteflowering pea cultivars (Avia, Laser, Madonna and Miami) Kluth et al. (2005) observed that the cultivar with the lowest AA digestibility caused the lowest energy digestibility both at 150 and $300 \mathrm{~g} / \mathrm{kg}$ diet. The inclusion of peas in broiler diets increased feed intake and decreased gain:feed ratio (Czerwi $\square$ ski et al., 2010). Thacker et al. (2013) stated that increasing the availability of phosphorus in peas meant that less inorganic phosphorus would be required to meet the nutritional requirements of broilers.

The effect of different levels of raw grass pea caused a remarkable decrease in gross energy and lipid apparent digestibility (Riasi et al., 2015). Spielmann

Table 3 - Relative levels of serum proteins of 42 -d-old broilers fed the experimental diets (C: control, P20: $20 \%$ of the dietary protein derived from peas, P40: $40 \%$ of the dietary protein derived from peas).

\begin{tabular}{|c|c|c|c|c|c|c|c|}
\hline Diets & Albumin & Alpha1 globulin & Alpha2 globulin & Beta globulin & Gamma globulin & Total Protein & A/G ratio \\
\hline$C$ & $32.17 \pm 1.42$ & $12.23 \pm 1.53$ & $16.71 \pm 1.54$ & $14.58 \pm 0.96$ & $24.11 \pm 1.78^{\mathrm{ab}}$ & $2.39 \pm 0.09$ & $0.48 \pm 0.03$ \\
\hline P20 & $28.37 \pm 2.87$ & $14.18 \pm 2.07$ & $14.17 \pm 1.33$ & $17.21 \pm 1.20$ & $26.97 \pm 1.13^{b}$ & $2.96 \pm 0.17$ & $0.44 \pm 0.06$ \\
\hline P40 & $34.93 \pm 1.95$ & $15.33 \pm 1.08$ & $15.63 \pm 2.11$ & $16.07 \pm 1.59$ & $21.53 \pm 1.01^{\mathrm{a}}$ & $2.46 \pm 0.07$ & $0.49 \pm 0.02$ \\
\hline
\end{tabular}

a, bMeans with different superscripts within a column are significantly different $(p<0.05)$.

Table 4 - Serum protein fractions ( $\mathrm{g} / \mathrm{L}$ ) of 42 -d-old broilers fed the experimental diets (C: control, P20: $20 \%$ of the dietary protein derived from peas, P40: $40 \%$ of the dietary protein derived from peas).

\begin{tabular}{|c|c|c|c|c|c|}
\hline Diets & Albumin & Alpha1 & Alfa2 & Beta & Gama \\
\hline C & $0.817 \pm 0.053$ & $0.295 \pm 0.044$ & $0.372 \pm 0.048$ & $0.330 \pm 0.0259^{b}$ & $0.575 \pm 0.046$ \\
\hline P20 & $0.826 \pm 0.059$ & $0.440 \pm 0.083$ & $0.414 \pm 0.031$ & $0.542 \pm 0.067^{a}$ & $0.800 \pm 0.056$ \\
\hline P40 & $0.895 \pm 0.077$ & $0.400 \pm 0.034$ & $0.458 \pm 0.065$ & $0.376 \pm 0.037^{b}$ & $0.535 \pm 0.035$ \\
\hline
\end{tabular}

$a, b$ Means with different superscripts within a column are significantly different $(p<0.05)$. 
et al. (2008) observed that pea protein has a low methionine content and a high arginine content. The addition of pea meal as a source of protein into broiler diets can improve carcass quality and may result in favorable lipid profile, without adversely affecting growth performance traits (Igbasan \& Guenter, 1996; Pilarski et al., 2005; Laudadio et al., 2012).

The broiler serum proteins and fractions can be affected by the application of different feedstaff (Bingol et al., 2016). In this study, total protein concentrations in group P20 were significantly higher than in group P40 $(p<0.05)$. It may be assumed that pea amino acid composition influenced total protein concentration, and that resulted from the differences among globulin fractions.

Albumin influences osmotic pressure balance and the transport of substances in the blood. Albumin also prevents blood from leaking out of the vessels (Adkins et al., 2002; Metzler \& Metzler, 2003; Prinsen et al., 2004; Jacobs et al., 2005; SPEP). In the present study, no changes in albumin percentage or concentration were observed, suggesting that pea proteins may affect mostly globulin fractions.

Serum globulin concentrations are followed up in liver diseases, chronic infections, acute diffuse glomerulonephritis, sarcoidosis, carcinomas and autoimmune diseases (Karagul et al., 2000; Turgut, 2000; Mehmetoglu, 2002; SPEP). The alpha-1 globulin fraction include $\left(\alpha_{1}\right.$-antitrypsin, $\alpha_{1}$-acid glycoprotein, $\alpha_{1}$-lipoprotein (Apolipoprotein A), $\alpha_{1}$-fetoprotein (AFP), transcortine, protein connecting thyroxine, glycoprotein) (Turgut, 2000; Mehmetoglu, 2002; SPEP). Pea proteins markedly reduces blood cholesterol and triglyceride levels in rats (Martins et al., 2004; Rigamonti et al., 2010; Sirtori et al., 2012). Dietary pea has a lowering effect on the blood lipid concentrations of rats (Spielmann et al., 2008). Pea protein contains low methionine and high arginine levels, and this is important for the hypocholesterolemic effect. Dietary pea addition promoted cholesterol conversion into bile acid in hamsters fed a high fat diet, thereby exerting hypolipidemic activity, which was attributed to the fact that pigeon pea contained high unsaturated fatty acid levels (Dai et al., 2013). Pea protein stimulates the formation and excretion of bile acids, which reducing hepatic cholesterol concentration and a reduced cholesterol secretion via VLDL (Spielmann et al., 2008).

The alpha-2 globulin fraction includes important metabolic and acute-phase proteins, such as $\alpha 2-$ macroglobulin and haptoglobin (Mehmetoglu, 2002; Gungor etal., 2004; SPEP). In this study, the percentages and concentrations alpha1 and alpha2 globulins were not statistically different among groups. The pea levels added to the diets in the present experiment did not affect alpha-globulin levels.

Beta-globulin proteins help to transport substances, such as iron, through the bloodstream, and help fighting against infections (Karagul et al., 2000; SPEP). Beta-globulin concentrations were higher in group P20 compared with both $C$ and P40 groups in the current study.

Gamma globulins are also called antibodies, which help to prevent and fight against infections. Gamma globulins bind to foreign substances, such as bacteria or viruses, causing them to be destroyed by the immune system. Immunoglobulins and the C-reactive protein (CRP) migrate in the $\gamma$-globulin area (Erstad 1996; Karagul et al., 2000; Mehmetoglu 2002; Murray, 2003). The long-term intake of pea fiber (PF) was shown to improve colonic function via altering colonic barriers, colonic immunity, and metabolismrelated protein gene expressions (Che et al., 2014). The percentages and concentrations gamma globulin were greater in group P20 compared with group P40 in the current study $(p<0.05)$.

Pea proteins increased beta- and gamma-globulin fractions, particularly when added at $20 \%$ of dietary CP level. Therefore, both this level and period of inclusion seem to be ideal for broiler chickens. It should be noted that concentration and percentage of gammaglobulin fractions when $20 \%$ pea protein was added to the basal diet, indicating that pea may stimulate the synthesis of proteins associated with immunity.

No changes in blood $A / G$ ratio where observed in the pea-fed groups, despite the increase in total globulin concentration.

This study showed that albumin, alpha-1, and alpha-2 globulin concentrations and A/G ratio were not affected by dietary pea addition. However, the replacement of $20 \%$ soybean protein with pea protein significantly increased the blood concentrations of beta and gamma-globulins and total protein of broilers. Considering that addition of pea in the basal diet may stimulate the synthesis of proteins of the beta- and gamma-globulin fractions, further studies to determine the optimal level of pea addition to broiler diets are warranted.

\section{CONFLICT OF INTERESTS STATEMENT}

The authors have no conflict of interest regarding the publication of this article. 


\section{REFERENCES}

Adkins JN, Varnum SM, Auberry KJ, Moore RJ, Angell NH, Smith RD, et al. Toward a human blood serum proteome: Analysis by multidimensional separation coupled with mass spectrometry. Molecular \& Cellular Proteomics 2002;1:947-955

Bingol NT, S Dede, MA Karsli, O Yilmaz, I Turel, V Yuksek. Effects of plantago major extract on serum protein fractions in broiler diet. Indian Journal of Animal Research,2016;DOI: http://dx.doi.org/10.18805/ijar.9641.

Che L, Chen H, Yu B, He J, Zheng P, Mao X, et al. Long-term intake of pea fiber affects colonic barrier function, bacterial and transcriptional profile in pig model. Nutrition and Cancer 2014;66(3):388-399.

Cowieson AJ, Acamovic T, Bedford MR. Supplementation of diets containing pea meal with exogenous enzymes: effects on weight gain, feed conversion, nutrient digestibility and gross morphology of the gastrointestinal tract of growing broiler chicks. British Poultry Science 2003;44(3):427-437.

Czerwicski J, Højberg O, Smulikowska S, Engberg RM, Mieczkowska A. Influence of dietary peas and organic acids and probiotic supplementation on performance and caecal microbial ecology of broiler chickens. British Poultry Science 2010;51(2):258-269.

Dai FJ, Hsu WH, Huang JJ, Wu SC. Effect of pigeon pea (Cajanus cajan L.) on high-fat diet-induced hypercholesterolemia in hamsters. Food and Chemical Toxicology 2013;53:384-391.

Erstad BL. Viral infectivity of albumin and plasma protein fraction. Pharmacotherapy 1996;16:996-1001.

Gungor O, Sunar B, Ozcelik F, Aktas Z, Suer Gokmen S. Sialic acid levels in acute myocardial infarction and the relationship with ceruloplasmin. Turkish Journal of Biochemistry 2004;29:226-231.

NRC - National Research Council. Nutrient requirement for poultry. 9thed. Washington: National Academiy Press; 1994. Available from: http:// www.pjbs.org/ijps/fin182.pdf.

Igbasan FA, Guenter W. The enhancement of the nutritive value of peas for broiler chickens: an evaluation of micronization and dehulling processes. Poultry Science 1996;75(10):1243-1252.

Jacobs JM, Adkins JN, Qian WJ, Liu T, Shen Y, Camp II DG, et al. Utilizing human blood plasma for proteomic biomarker discovery. Journal of Proteome Research 2005;4(4):1073-1085.

Karagul H, Altintas A, Fidanci UR, Sel T. Clinical Biochemistry. Ankara: Medisan Inc; 2000. p. 161-164.

Kluth H, Mantei M, Elwert C, Rodehutscord M. Variation in precaecal amino acid and energy digestibility between pea (Pisum sativum) cultivars determined using a linear regression approach. British Poultry Science 2005;46(3):325-332

LaudadioV, Nahashon SN, Tufarelli V. Growth performance and carcass characteristics of guinea fowl broilers fed micronized-dehulled pea (Pisum sativum L.) as a substitute for soybean meal. Poultry Science 2012;91(11):988-2996.

Laudadio V, Tufarelli V. Growth performance and carcass and meat quality of broiler chickens fed diets containing micronized-dehulled peas (Pisum sativum cv. Spirale) as a substitute of soybean meal. Poultry Science 2010;89:1537-1543.

Longstaff $M$, McNab JM. Digestion of starch and fibre carbohydrates in peas by adult cockerels. British Poultry Science 1987;28:261-285.

Malley A, Baecher L, Mackler B, Perlman F. The isolation of allergens from the green pea. Journal of Allergy and Clinical Immunology 1975;56(4):282-290

Manojlović Z, Kopitar Z, Lenardic A, Plavsić F. Changes in plasma proteins and drug distribution in kidney and liver diseases. Lijecnicki Vjesnik. 1993;115:366-369.

Mariotti F, Pueyo ME, Tomé $D$, Bérot $S$, Benamouzig $R$, Mahé $S$. The influence of albumin fraction on bioavailability and postprandial utilization of pea protein given selectively to humans. The Journalof Nutrition 2001;131:1706-1713.

Martins JM, Riottot M, Abreu MC, Lança MJ, Viegas-Crespo AM, Almeida $J A$, Freire JB, et al. Dietary raw peas (Pisum sativum L.) reduce plasma total and LDL cholesterol and hepatic esterified cholesterol in intact and ileorectal anastomosed pigs fed cholesterol-rich diets. Journal of Nutrition 2004;134(12):3305-3312.

Mehmetoglu I. Clinical Biochemistry Manual; Konya: Inci Offset; 2002. p. 124-129.

Metzler DE, Metzler CM. Biochemistry: the chemical reactions of living cells.2nded. London: Academic Press; 2003. p.58.

Murray RK. Plasma proteins and immunoglobulins. In: Murray RK, Granner DK, Mayes PA, Radwell VW, editors. Harper's illustrated biochemistry. 26thed.New York: Mc Graw Hill; 2003. p.580-582.

Musa MM, Elamin KM, Ati KA, Elagib HA, Musa AM. Effect of dietary levels of decorticated cow pea (Vigna unguiculata) supplemented with molasses on broiler chicks performance and carcass traits. Pakistan Journal of Biological Sciences 2012;15(21):1010-1018.

Pilarski R, Bednarczyk M, Lisowski M, Rutkowski A, Bernacki Z, Warde $\square$ ska $M$, et al. Assessment of the effect of alpha-galactosides injected during embryogenesis on selected chicken traits. Folia Biologica Krakow 2005;53(1/2):13-20

Prinsen B, Monique GM, Velden S. Albumin turnover: experimental approach and its application in health and renal diseases. Clinica Chimica Acta 2004;347(1/2):1-14.

Ravindran V, Blair R. Feed resources for poultry production in Asia and Pacific. 2. Plant protein sources. World Poultry Science Journal 1992;48:205-231

Riasi A, Mahdavi AH, Bayat E. Effect of different levels of raw and heated grass pea seed (Lathyrus sativus) on nutrient digestibility, intestinal villus morphology and growth performance of broiler chicks. Journal of Animal Physiology and Animal Nutrition 2015;99(5): 924-931.

Rigamonti E, Parolini C, Marchesi M, Diani E, Brambilla S, Sirtori CR, Chiesa G. Hypolipidemic effect of dietary pea proteins: Impact on genes regulating hepatic lipid metabolism. Molecular Nutrition \& Food Research 2010;54:S24-S30.

Sirtori CR, Triolo M, Bosisio R, Bondioli A, Calabresi L, De Vergori $V$, Gomaraschi M, et al.. Hypocholesterolaemic effects of lupin protein and pea protein/fibre combinations in moderately hypercholesterolaemic individuals. British Journal of Nutrition 2012;107(8):1176-1183.

SPEP. Serum protein electrophoresis. 2016. Available from: http://www. webmd.com/cancer/lymphoma/serum-protein-electrophoresis-spe.

Spielmann J, Stangl Gl, Eder K. Dietary pea protein stimulates bile acid excretion and lowers hepatic cholesterol concentration in rats. Journal of Animal Physiology and Animal Nutrition 2008;92(6):683-693.

Thacker P, Deep A ,Petri D, Warkentin T. Nutritional evaluation of lowphytate peas (Pisum sativum L.) for young broiler chicks. Archives of Animal Nutrition 2013;67(1):1-14.

Titus HW, Fritz JC. Percentage multipliers for computing metabolizable energy values, for chickens, of some feedstuffs used in the feeding of poultry. In: The scientific feeding of chickens. $5^{\text {th }}$ ed. Danville: Interstate; 1971. p.295- 298

Turgut K. Veteriner Klinik Laboratuar Teşhis, Gelistirilmis 2. Konya: Bahcivanlar Basim Sanayi; 2000. p. 496.

Vicenti A, Toteda F, Di Turi L, Cocca C, Perrucci M, Melodia L, et al. Use of sweet lupin (Lupinus albus L. var. Multitalia) in feeding for Podolian young bulls and influence on productive performances and meat quality traits. Meat Science 2009;82:247-251. 
